UDK 78.087.681Savin

Špela Lah

Filozofska fakulteta, Univerza v Ljubljani

Faculty of Arts, University of Ljubljana

\title{
Otroški in mladinski zborovski opus Rista Savina
}

\section{Risto Savin's Works for Children's and Youth Choirs}

Prejeto: 13. junij 2012

Sprejeto: 14. september 2012

Ključne besede: Risto Savin, otroški zbori, mladinski zbori

IZVLEČEK

Članek predstavi analitični prerez Savinovega opusa za otroški in mladinski zbor ter poda njegove bistvene kompozicijske značilnosti.
Received: 13th June 2012

Accepted: 14th September 2012

Keywords: Risto Savin, children's choruses, youth choruses

Abstract

The article presents an analytical profile of Savin's works for children's and youth choirs and outlines their main compositional characteristics.

Risto Savin je posegel na področje otroškega in mladinskega zborovstva v času, ko je to v ustvarjalni in poustvarjalni praksi že dosegalo vidne uspehe. Mladi skladatelji z Emilom Adamičem in Marijem Kogojem na čelu so tej zvrsti že pred prvo svetovno vojno postavili pomembne temelje in povzdignili kakovost tovrstne literature, Slavko Osterc jo je do leta 1940 pomembno obogatil, zborovodji Avgust Šuligoj in Radovan Gobec, ki sta se povzpela na raven odličnih interpretov, pa sta jo približala mladim pevcem. ${ }^{1}$ Prav vedno večji uspehi posameznih mladinskih zborov tistega obdobja, še posebno Trboveljskega slavčka, so spodbudili Savina k prvemu poskusu ${ }^{2}$ na tem področju, kateremu je nato posvetil večji del svoje ustvarjalne moči v zadnjem desetletju svojega življenja.

Skladateljev prispevek otroškemu in mladinskemu zborovstvu je ostal do sedaj na obrobju zanimanja slovenskih glasbenih zgodovinarjev in neznan širši javnosti. Dela so

Cvetko Budkovič, Razvoj mladinskega zborovskega petja na Slovenskem od začetkov do druge svetovne vojne (Ljubljana, Partizanska založba, 1983).

2 Na področje mladinske glasbene literature je Savin prvič vstopil pravzaprav že z moškim zborom Mladi mucek z miško pleše, op. 32/2 (1935). Prim. Dragotin Cvetko, Risto Savin: Osebnost in delo (Ljubljana: Državna založba Slovenije, 1949), 159-160. 
bila namreč do danes zabeležena, popisana in analitično predstavljena le v diplomski ("Risto Savin - analiza zborovskih del ") 3 in magistrski nalogi ("Problemi poustvarjanja mladinskih in otroških zborovskih del skladatelja Rista Savina «) ${ }^{4}$ Gorazda Kozmusa. Namen pričujočega članka je zato odpraviti nastalo vrzel in Savinove zbore približati še posebno slovenski glasbeni stroki.

Pod vtisom, da ima mladinsko zborovsko petje vendarle premalo ustrezne, predvsem lahkotne in radožive literature, ${ }^{5}$ je leta 1938 napisal svoji prvi dve skladbi te zvrsti, Maj (št. 1) ${ }^{6}$ in Tecimo (št. 2) ${ }^{7}$, ki ju je združil v opusu 36. Skladbici sta kratki, z jasno tridelno A-B-A shemo. Medtem ko se prva giblje v optimističnem G-duru, je besedilo slednje skladatelju narekovalo izbor d-mola. Obe sta svetli, blizu otroškemu dojemanju, a tehnično precej zahtevni. Predvsem prva je bila pogosto na sporedih zbora iz Rakeka, ki ga je tedaj vodil Makso Pirnik. Pirnik, ustanovitelj Društva pevovodij mladinskih zborov, je tedaj veljal za enega vodilnih zborovodij pri nas. Savin se je z njim zbližal na pobudo Slavka Osterca in z njim stkal tesno prijateljsko vez, ki je pomembno vplivala na skladateljevo nadaljnje ustvarjanje in bila živa vse do njegove smrti. ${ }^{8}$

Ugoden odziv je pokazal, da je bila Savinova glasbena invencija kljub visoki starosti ali pa prav zaradi nje (leta 1938 je bil že na pragu osemdesetega leta) še vedno dovolj mladostna. Kmalu zatem, v letih 1940-41, je zato nastala nova zbirka petih mladinskih del, zbranih v opusu 40: Pomladi (št. 1), Luna dremlje (št. 2), Materino srce (št. 3), Tja $v$ ogradi (št. 4) in Tički po zraku letajo (št. 5). ${ }^{9}$ Opus je slogovno zaokrožen in izrazno najbolj sodoben med Savinovimi mladinskimi zbori. Skladbe se precej razlikujejo od opusa 36, kar se kaže tako v vsebinskosti pesmi, ki se oddalji od otroške radoživosti, kot tudi v kompleksni harmoniji in izvajalski zahtevnosti. Vse so pisane v svetlih durovih tonalitetah (D-dur, C-dur, D-dur, C-dur, F-dur) s preprostima ritmično fakturo in oblikovno zasnovo.

Po naročilu Pirnika, ki se je po končani drugi svetovni vojni vrnil iz Bele krajine v Ljubljano in postavil otroški zbor na ljubljanskem učiteljišču, se je leta 1946 Savin prvič lotil komponiranja za otroško zasedbo. Napisal je skladbici Pastirčki (št. 1) in Kroparji (št. 2), ${ }^{10}$ združeni v opusu 42. Kasneje pa se k tovrstnemu sestavu ni več vrnil, čeprav sta bili skladbici dobro sprejeti, tudi po zaslugi kakovostnih izvedb Pirnikovega zbora na učiteljišču. ${ }^{11}$

Poslednja leta svojega bogatega življenja je Savin strnil s tremi opusi za mladinski zborovski sestav. Še istega leta je nastal op. 44 za dekliški ali ženski zbor, ki združuje dve izrazno moderni, tehnično zahtevni ter harmonsko bogati skladbi Trobentica, št. 1 in

\footnotetext{
Gorazd Kozmus, Risto Savin - analiza zborovskih del (Diplomsko delo, Akademija za glasbo, Ljubljana, 1997).

Gorazd Kozmus, Problemi poustvarjanja mladinskih in otroških zborovskih del skladatelja Rista Savina (Magistrsko delo, Akademija za glasbo, Ljubljana, 2002).

5 Savinovo pismo Slavku Ostercu 8. junija 1938. Prim. Suzana Ograjenšek, Dopisovanje Rista Savina o glasbi in slovenskem glasbenem dogajanju (Diplomska naloga, Filozofska fakulteta, Oddelek za muzikologijo, Ljubljana, 1999 ), 55.

Natis: Mladinske pesmi (Slovenske konjice: Društvo pevovodij mladinskih zborov, 1938); Naši zbori 1, št. 1 (1946).

Skladbica je ohranjena $v$ rokopisu.

Cvetko, Risto Savin ..., 162; Ograjenšek, Dopisovanje Rista Savina ..., 55-68.

Natis: Ljubljana: Mladinska knjiga, 1946.

Natis: Ljubljana: Mladinska knjiga, 1947.

Ograjenšek, Dopisovanje Rista Savina ..., 69-71.
} 
Lahko noč, ${ }^{12}$ št. 2 (čas nastanka slednje je vprašljiv). ${ }^{13}$ Obe zaznamuje durova tonaliteta (A-dur in As-dur) in enostaven ritmični tok.

Leto za tem je Savin napisal op. 45 (Vihra, št. 1 in Pust, pust, št. 2), ${ }^{14}$ v katerih postaja glasbena govorica ponovno bolj razigrana, kar nakaže že izbor besedil. Skladbi se gibljeta v svetlih durovih tonalitetah (E-dur, C-dur), predvsem prva pa je harmonsko še vedno precej kompleksna in izrazno zahtevna. ${ }^{15}$ Nasprotno se je skladatelj v zboru Pust, pust odpovedal v prejšnjih opusih značilni zahtevnosti in nakazal nov kompozicijski pristop, ki zaznamuje poslednji opus, opus $46 \mathrm{~s}$ petimi skladbicami (št. 1: Vrabci in strašilo, št. 2: Zvonovi, št. 3: Uspavanka, št. 4: Stari medo ter št. 5: Pesem nagajivka). ${ }^{16}$ Skladbe so lahkotne in živahne ter manj zapletene, vse so napisane v durovih tonalitetah (C-dur, Es-dur, G-dur, D-dur, C-dur) ter ritmično in oblikovno preproste.

Kompozicijska in muzikalna zasnova Savinovih otroških in mladinskih zborov izvira iz pesniških predlog. Te je skladatelj izbiral premišljeno in skrbno. ${ }^{17}$ Najpogosteje je posegel po verzih Otona Župančiča (opusa 42 in 46) in Danila Gorinška (opusa 36 in 44 ter op. 40/3), dvoje besedil je prišlo izpod peresa Ivana Albrehta (Luna dremlje in Tja $v$ ogrado), po eno pa od Toneta Gasparija (Pust, pust) in Vide Jerajeve (Pomladi). Le enkrat je Savin izbral za predlogo ljudsko pesem (Tički po zraku letajo), Vihra, izvirno Veter, pa je delo neznanega avtorja. Izbiral je živahne, mladostno razigrane in šaljive tekste, blizu so mu bila tudi razpoloženjska besedila, ki slikajo naravo (glej Tabelo 1). Savinu je bila pesniška vsebina izbranih besedil pomembna, saj jo je skušal kar najtesneje povezati z glasbeno. Oblikovno in kompozicijsko-tehnično je namreč izhajal iz tekstovne predloge, katere strukturo je po potrebi prilagodil lastni invenciji. Besedilo torej ni bilo oblikovno zavezujoče, pač pa je skladatelju nudilo bogat vir umetniške inspiracije.

Za otroški zbor je Savin uglasbil le Župančičeve Pastirčke in Kroparje. Da se k tovrstnemu sestavu kasneje ni več povrnil, je bržkone krivo dejstvo, da mu je bila zasedba za otroški zbor preozka in premalo barvita. ${ }^{18}$ To se kaže tudi v razmeroma visoki zahtevnosti skladbic za male pevce: medtem ko so Kroparji zasnovani kot enoglasen zbor s (pre) velikim glasovnim razponom do $e^{2}$ ter s preprosto, a otroškemu umevanju privlačno klavirsko spremljavo, so Pastirčki napisani večglasno in nekoliko bolj kompleksno. Skladatelj je pesem zasnoval za otroški zbor, solistično skupino sedmih fantov, ki simbolizira Župančičevih »sedmero pastirčkov «, in klavirsko spremljavo. ${ }^{19}$ Oblikoval jo je kot tridelno pesemsko miniaturo a-b-c s codo. Vsak del ima svoj značaj, prilagojen vsebinskim značilnostim posamične kitice. Vrhunec skladbe je srednji b del, v katerem se predstavijo pastirčki. Savin ga je zasnoval kot kanonsko fakturo, v kateri se dosledno izmenjujeta solistična skupina in zbor (zbor dosledno ponovi verz, ki ga najprej zapoje

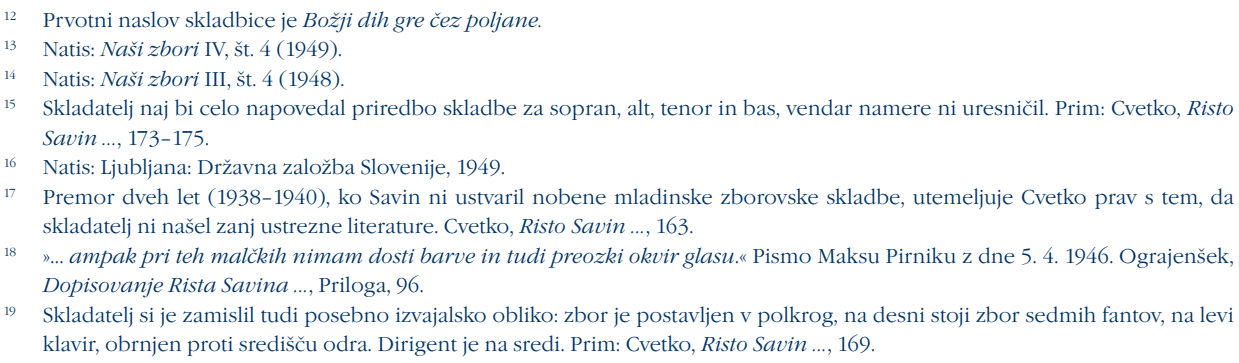

18 "... ampakpri teh malčkih nimam dosti barve in tudi preozki okvir glasu. Pismo Maksu Pirniku z dne 5. 4. 1946. Ograjenšek, Dopisovanje Rista Savina ..., Priloga, 96.

19 Skladatelj si je zamislil tudi posebno izvajalsko obliko: zbor je postavljen v polkrog, na desni stoji zbor sedmih fantov, na levi klavir, obrnjen proti središču odra. Dirigent je na sredi. Prim: Cvetko, Risto Savin ..., 169. 
sedem dečkov). Vsebinskemu razvoju pripomorejo tudi spremembe tonalitete (c - G - Es) in takta $(\mathrm{C}-6 / 8-\mathrm{C}-6 / 8$ ) posameznih delov skladbe, dinamična stopnjevanja in spreminjanje tempa od počasnega Lento, ki predstavi težko življenje pastirjev, preko živahnega Allegra do zmagoslavnega Maestoso, s katerim skladatelj poudari zmago pastirčkov nad težkimi časi.

Tabela 1: Seznam avtorjev besedil in prvih verzov v otroških in mladinskih zborih Rista Savina

\begin{tabular}{|c|c|c|c|}
\hline Naslov & Opus & Avtor besedila & Prvi verz \\
\hline \multicolumn{4}{|l|}{ OTROŠKA ZBORA } \\
\hline Kroparji & $42 / 1$ & Oton Župančič & Kdo pa tisti so štorkljači? \\
\hline Pastirčki & $42 / 2$ & Oton Župančič & Bilo je sedem suhih let... \\
\hline \multicolumn{4}{|l|}{ MLADINSKI ZBORI } \\
\hline$M a j$ & $36 / 1$ & Danilo Gorinšek & Aj, aj, aj, zazelenil maj \\
\hline Tecimo & $36 / 2$ & Danilo Gorinšek & Nočprihaja, črna ptica... \\
\hline Pomladi & $40 / 1$ & Vida Jerajeva & Oj zbogom črne senčice... \\
\hline Luna dremlje & $40 / 2$ & Ivan Albreht & Luna dremlje, sonce spi... \\
\hline Materino srce & $40 / 3$ & Danilo Gorinšek & Bel, bela, hišica,... \\
\hline Tja v ogrado & $40 / 4$ & Ivan Albreht & Tja v ogrado se bom skril... \\
\hline Tički po zraku letajo & $40 / 5$ & slovenska narodna & Tički po zraku letajo... \\
\hline Trobentice & $44 / 1$ & Danilo Gorinšek & To žarijo vse poljane... \\
\hline $\begin{array}{l}\text { Lahko noč (Božji dih } \\
\text { gre čez poljane) }\end{array}$ & $44 / 2$ & Danilo Gorinšek & Vse že spi, nič zvezdic ni... \\
\hline Pust, pust & $45 / 1$ & Tone Gaspari & Pust, pust, krivih ust \\
\hline Vihra & $45 / 2$ & $\mathrm{nn}$ & Vihra sem, vihra, naglo letim \\
\hline Vrabci in strašilo & $46 / 1$ & Oton Župančič & $\begin{array}{c}\text { Čiv čiv, čiv čiv, še dolgo bom } \\
\check{z ̌ i v ! ~}\end{array}$ \\
\hline Zvonovi & $46 / 2$ & Oton Župančič & $\begin{array}{c}\text { Bim bim, bim bim! Jaz dan } \\
\text { zvonim ... }\end{array}$ \\
\hline Uspavanka & $46 / 3$ & Oton Župančič & Kaj bo sinku sen prineslo? \\
\hline Stari medo & $46 / 4$ & Oton Župančič & $\begin{array}{c}\text { Brunda gunda, brunda } \\
\text { gunda, ... }\end{array}$ \\
\hline Pesem nagajivka & $46 / 5$ & Oton Župančič & $\begin{array}{l}\text { Zima, zima bela, vrh gore } \\
\text { sedela, ... }\end{array}$ \\
\hline
\end{tabular}

Pri skladateljevih mladinskih zborih je večina uporabljenih pesemskih predlog kitične oblike; v svobodni pesniški obliki je pisana pesem Pomladi, katero skladatelj uresniči v ustrezni prekomponirani obliki. Vendar kitična struktura ne pogojuje zunanjega skeleta kompozicije, saj sledi skladatelj, kot rečeno, notranjemu občutenju in umevanju teksta. Pri tem se ne omejuje na stroge zakonitosti glasbenega stavka, šablonska togost v smislu osem-taktne periodizacije je zato redka. Posamične dele skladb razširi ali skrajša, kakor ga pri tem vodi vsebinski moment poezije. Pogosto posežev sam konstrukt predloge, kar se kaže na primer v večkratnem ponavljanju posamične besede (npr. Pesem nagajivka; 
Trobentice; Lahko noč) ali cele fraze (npr. Vihra; Pastirčki; Pomladi; Tecimo).

Posamezni deli glasbenega stavka so med seboj največkrat jasno ločeni. Kontraste med odseki Savin gradi v prvi vrsti z menjavo tonalitete oziroma s tonalnimi odmiki. Metrične spremembe med posamičnimi deli skladb niso pogoste (Maj; Tecimo; Pastirčki; Vihra), še bolj zadržan je pri uvajanju novih ritmičnih vzorcev v poteku skladbe (večje ritmične spremembe so značilne v skladbah Tecimo, Pomladi in Tički po zraku letajo). Najbolj učinkoviti so kontrasti, v harmonskem toku, ki je tesno odvisen od spremembe tempa: pogost je prehod v hiter tempo, ki hkrati zahteva izčiščen harmonski stavek; in obratno, počasni odseki omogočajo več harmonske zgoščenosti in drznosti ter umik v tonalno negotovost. Na ta način skladatelj učinkovito stopnjuje glasbeni tok do viška. ${ }^{20}$

Savin je veljal za izrazitega melodika, kar se kaže tudi v njegovih mladinskih zborih. Glasbeni tok je precej razgiban, čeprav širši loki niso pogosti (daljše melodične misli so značilne za zbore Pomladi, Materino srce, Tja v ogrado, Trobentice in Uspavanka). Glasbeno misel snuje razmeroma ozko, pogosto fragmentarno, značilno je gibanje v sekundnih in terčnih postopih. Večjih skokov je relativno malo; z njimi poudari določeno besedo ali nakaže začetek nove fraze in podčrta dramatični moment pesmi. $\mathrm{V}$ posamičnih primerih gradi s krajšimi motivčnimi celicami, ki se lahko variirano ali sekvenčno ponavljajo (Uspavanka; Zvonovi; Pesem nagajivka), toda samega pomena motivičnega dela načeloma ne dosežejo.

Zavoljo tesnega sledenja vsebini besedila skladatelj značilnosti melodičnega poteka pogosto spreminja znotraj same skladbe: gibanje glasbe na primer preide s spevnega valovanja na pripovedni značaj (Tecimo, Vihra); ali pa s širšega glasbenega fraziranja na fragmentarno členjenje ( $M a j$ ) ali na razgibano melodiko z značilnimi večjimi skoki (Tički po zraku letajo). Kot primer variabilnosti melodičnega toka naj služi zbor Pomladi, v katerem je Savin prosto glasbeno obliko pesemske predloge uresničil v kratki prekomponirani miniaturi. V prvem delu skladbe ${ }^{21}$ (primer 1) je verze besedila uglasbil z enakomerno tekočo in razgibano, valovito melodiko, ki izstopa v zgornjem glasu. Tak značaj ustreza razigranemu pričakovanju pomladi. Razpon med glasovi, ki so precej enakovredno obravnavani, je razmeroma velik, predvsem v spodnjem glasu pa je več skokov. Glasbeni tok z značilnim ritmičnim vzorcem se ne ustavi vse do kadenciranja ob zaključku prvega dela.

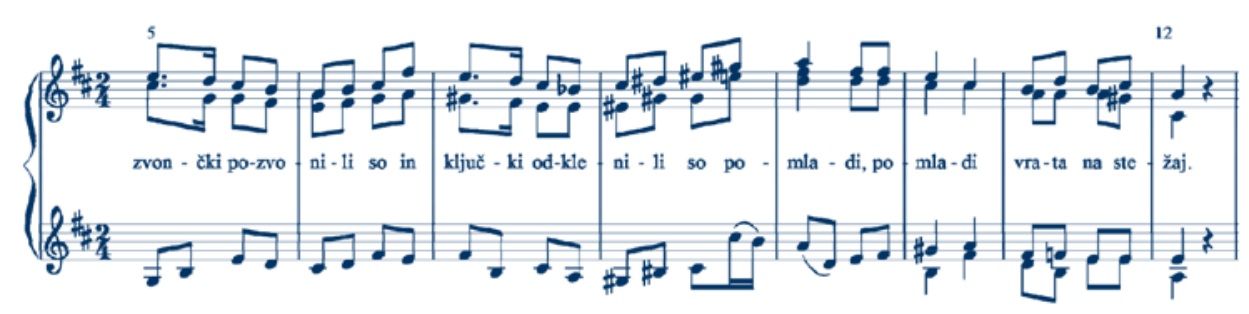

Primer 1: Pomladi (takt 5-12)

\footnotetext{
Glej notna primera 9 in 10.

${ }^{21}$ Uglasbitev verzov Oj zbogom črne senčice / zapele so trobentice / in zvončki pozvonili so / in ključki odklenili so / pomladi, pomladi vrata na stežaj.
} 
Skladatelj je v drugem delu skladbe 22 (primer 2) glasbeni izraz prilagodil nadaljnjemu poteku besedila »Kaj zopet si prišel nazaj?«, ko se s postopi navzgor in spremenjenim ritmičnim vzorcem s triolno figuro približa dikciji govora ter ga realizira v smislu dialoga med glasovi. Celotno fakturo harmonsko razredči, glasba poteka v pripovednem tonu, hudomušen značaj pesniške predloge pa podčrta s fragmentarnim členjenjem ter z dinamičnim in agogičnim stopnjevanjem.

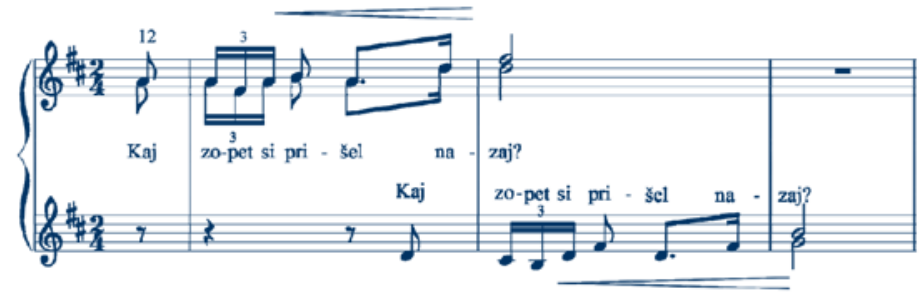

Primer 2: Pomladi (takt 12-15)

Kljub poudarjeni melodični invenciji je nekatere zbore (predvsem opus 46) zasnoval izrazito recitativno. Otroško razigrana besedila je opremil z drobljeno melodiko, s katero je učinkovito poudaril značaj pesmi (Maj; Pust, pust; Vrabci in strašilo; Zvonovi). Slikovit primer recitativne melodike je zbor danes že skoraj ponarodele Župančičeve pesmi Stari medo (primer 3). Osnova 3-glasne skladbice je pravzaprav dvoglasje zgornjih glasov, katerima postavi skladatelj v 'kontrapukt' tretji, spodnji glas, ki skuša to dvoglasje deformirati s ponavljajočim tonom in samostojnim gibanjem. Skladateljev domiselni pristop učinkovito ujame značaj pesmi in ji poda nov, svež ton.

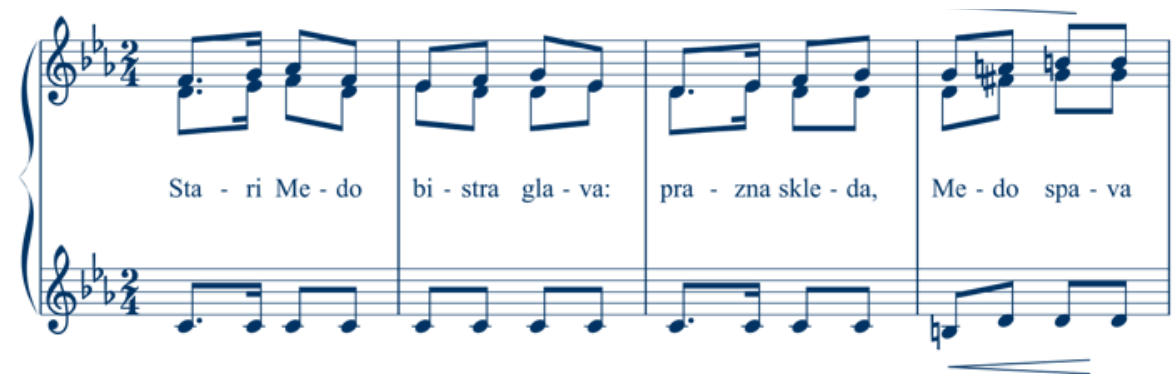

\section{Primer 3: Stari medo (takt 7-10)}

Uporaba recitativnega značaja izstopa v vseh uglasbitvah Župančičevih predlog v op. 46, tudi Uspavanki (primer 4), v kateri skladatelj na nek način ruši stereotipen pristop k tovrstni pesemski predlogi. Slednje namreč ne uresniči z morda pričakovanim širokim melodičnim lokom, saj je temelj skladbe recitativni ton, ki je prisoten v zasnovi triglasnega

22 Uglasbitev verzov Kaj zopet si prišel nazaj? / Zopet, ej zopet. / Ena, dve in tri, za mano / kdo me ulovi, / kdo me ulovi! 
stavka. Predvsem spodnji glas, ki se giblje okrog istega tona in sloni kot 'protiutež' zgornjima, narekuje harmonsko zamegljenost in tonalno negotovost. Svojevrsten melodični pristop, združen z ustreznim tempom (ki se postopoma upočasnjuje od Andante con moto do Lento) in izrazito enakomernim ritmom, se pokaže kot zelo učinkovit.
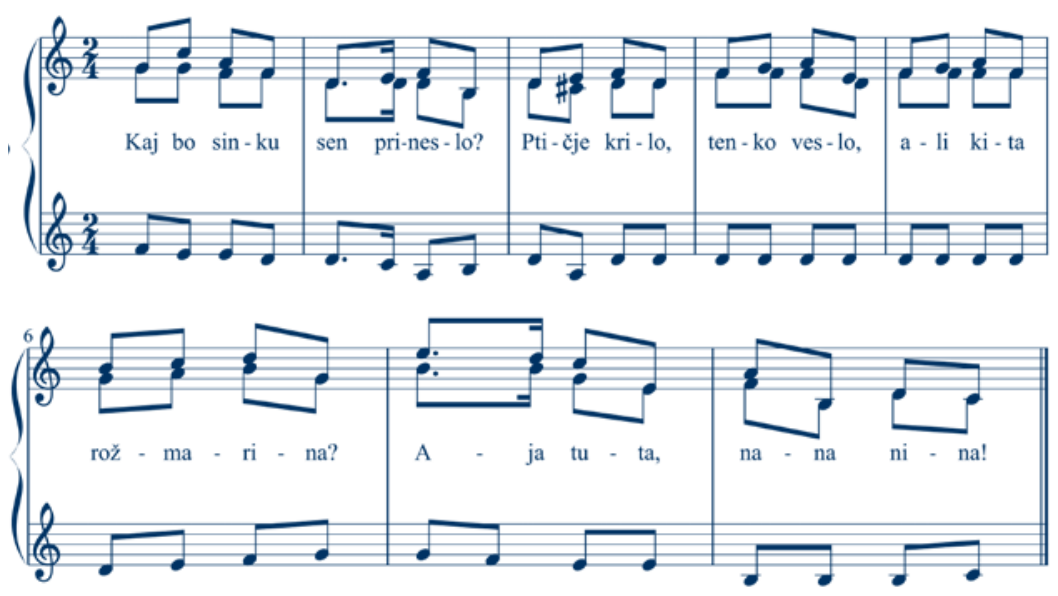

Primer 4: Uspavanka (takt 1-8)

Ambitus v Savinovih zborih je precej širok, predvsem sopranska lega je mestoma celo previsoka - melodični tok pripelje skladatelj vse do $\mathrm{a}^{2}$, za mladinske glasove izjemno visokega tona (Tecimo, Maj, Pomladi, Luna dremlja, Materino srce, Tički po zraku letajo, Trobentice). Značilna je silabična uglasbitev besedila, ki pa ni vedno dosledna (en ton na en zlog), saj melodiko večkrat obogati s krajšimi melizmi (najpogosteje dve noti na en zlog, izjemoma več).

Savina je v ustvarjalnem procesu vodila notranja invencija, v ospredju zanimanja pa mu je bil glasbeni izraz, ki ga je realiziral predvsem $s$ harmonsko govorico. Kljub odprtosti do novih kompozicijsko-tehničnih rešitev je ostal zvest tonaliteti. Tako je tudi za mladinsko zborovsko literaturo značilen moderen harmonski izraz, ki je največkrat hoteni rezultat samostojnega vodenja posameznih glasov. Melodična in harmonska struktura se v kompozicijskem postopku tesno navezujeta drug na drugega, glasovi pa so pogosto enakopravni in ne služijo le kot harmonska podlaga najvišjemu. Čeprav prevladuje homofona zasnova skladb, je očiten velik poudarek na linearnem vodenju posameznih glasov, zaradi česar so pogoste neobičajno postavljene akordične zveze, ki pa jih lahko utemeljimo na temelju tradicionalne dur-molovske funkcionalne harmonije. Pogoste so disonance v vertikalni gradnji, še posebno intervala sekunde in kvarte med sosednjimi glasovi, ter tudi kromatični postopi v linearnem vodenju glasov. Vendar disonančne nastope skladatelj vedno razveže in s tem sprošča napetost.

Primer linearnega toka je skladbica Materino srce. Kromatično protipostopno gibanje zunanjih glasov (primer 5) vodi v ostro sozvočje intervalov v tritonusnem razmerju esa-h-eis (takt 15), vendar pa je akord na nepoudarjeni dobi in je takoj razvezan v tonični kvintakord. 


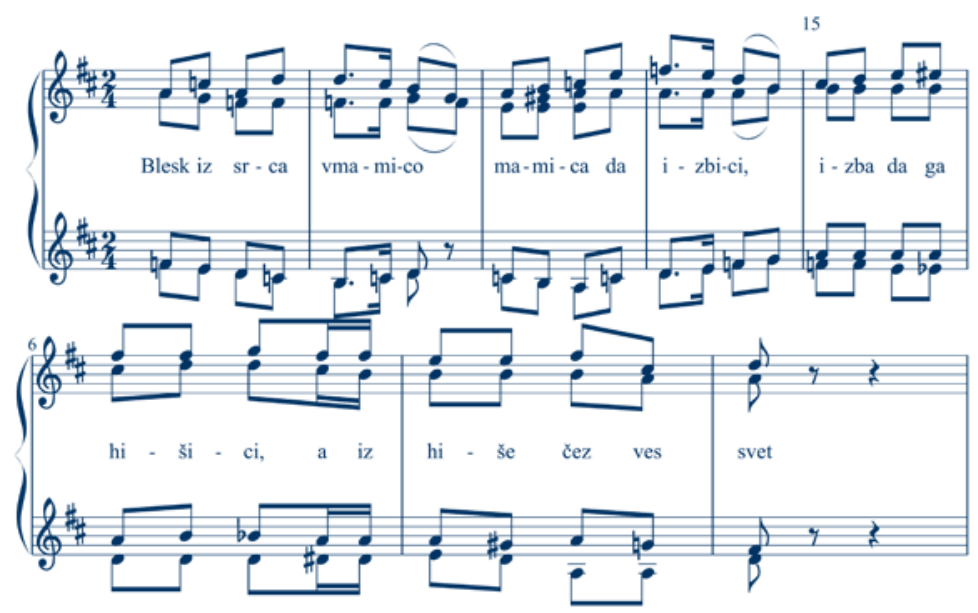

Primer 5: Materino srce (takt 11-18)

Poleg harmonsko tujih tonov so v Savinovih zborih za mladino značilne nenehne modulacije oziroma tonalni izmiki, v najbolj kompleksnih je harmonski ritem precej hiter. V pesmi Tja $v$ ogrado podčrta skladatelj značaj besedila s hitrimi harmonskimi spremembami, ko prinese vsak takt novo harmonijo. Harmonska govorica se izostri zaradi vsebinskega momenta, ko osrednji protagonist našteva, kakšne tri hiše si bo zgradil: "eno borovo«, d-mol; »eno brinjevo", h-mol; »eno lepo zidano«, osnovni C-dur (primer 6). Skladatelj že z izbranimi tonalitetami sugerira nadaljnji potek pesmi, namreč, kakšno ugodje nudi posamično domovanje (borova je smolna, v brinjevi je hudo, le v zidani ga čaka svetla prihodnost).

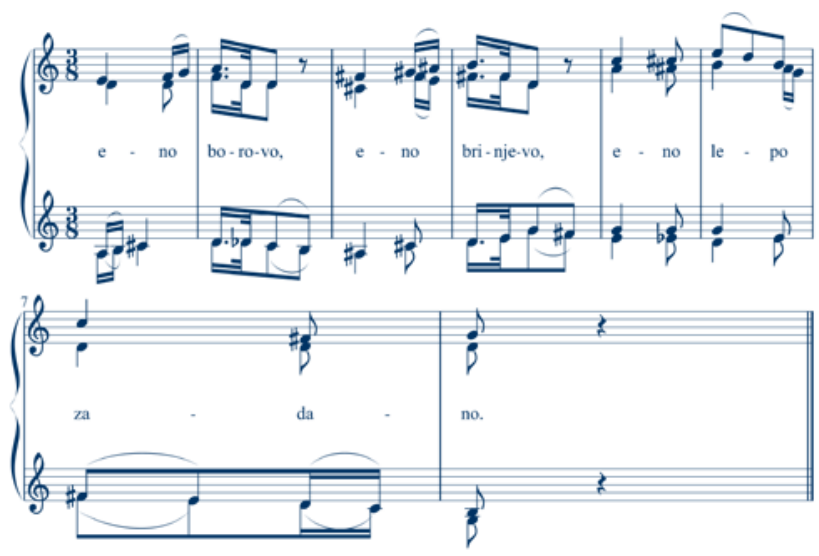

Primer 6: Tja v ogrado

Četudi je bil Savin v svojem kompozicijskem mišljenju izrazito 'vertikalen', izkazujejo skladbe linearno teksturo, ki je posledica prevladujoče samostojnosti glasov. Poudarjena 
vertikalna arhitektonika je zato v Savinovem mladinskem zborovskem opusu redka. Vertikalna zvočna struktura s prevladujočimi disonančnimi sozvočji zaznamuje na primer harmonsko enega bolj kompleksnih zborov Trobentica, v katerem je spodnji glas ponovno precej samostojen in kontrastira bogato 'obloženi' zgornji liniji z značilnimi tri- in četverozvoki (primer 7). S stopnjevanjem vsebinske 'teže' (»Je li živa to resnica?") se homofona struktura umakne razgibanemu nadaljevanju, ko dobi spodnji glas še bolj samostojno vlogo in tudi svoje besedilo. Dvom, ki ga sproži besedilo, se s ponujenim odgovorom ("Ne begotne sanje, v blesku le trobentice so vzklile») in doseženim viškom nasičen glasbeni tok postopno spušča in umirja.

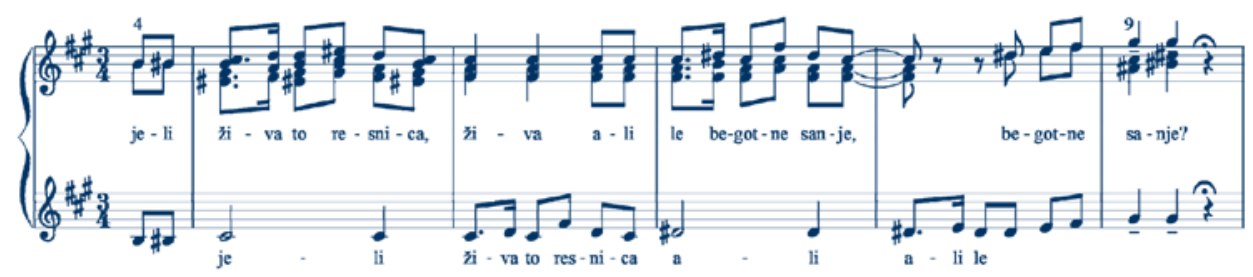

Primer 7: Trobentice (takt 4-9)

Ostali glasbeni parametri Savinovih zborov so izstopajoči harmonsko-melodični zasnovi večinoma podrejeni. Ritmični tok je enakomeren in preprost, skladatelj ga mestoma obogati s punktirano dobo ali hitrejšo ritmično figuro, da poudari vsebinske značilnosti pesemske predloge. Metrika skladb je prilagojena besednemu metrumu pesmi, prevladuje pa uporaba $2 / 4$ takta. Tridobnega metruma se je skladatelj poslužil le v zborih Tja $v$ ogradi in Zvonovi $(3 / 8)$ ter Trobentice in Vrabec in strašilo (3/4). Tudi v metrični realizaciji se je tesno navezoval na semantične značilnosti pesmi, zato zasledimo nekaj metričnih sprememb v poteku same skladbe (Tecimo, Maj, Pastirčki, Vihra). V tem oziru izstopa metrična struktura zbora Lahko noč, v katerem so metrični premiki C $-2 /{ }_{4}-3 /{ }_{4}-2 / 4$ razmeroma hitri (primer 8), pogojuje pa jih skladateljevo notranje umevanje teksta, ko glasbeni gradnji prilagodi verzno drobljenje in s tem poudari blagodejnost noči.

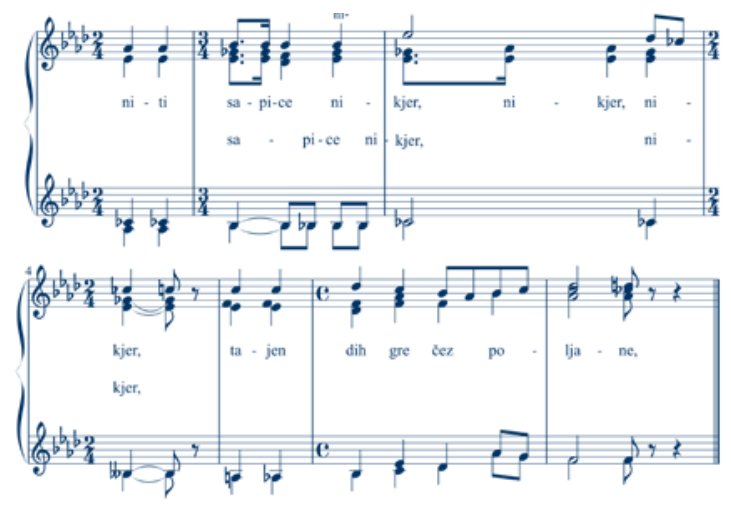

Primer 8: Lahko noč (takt 6-12) 
Tekstovna in glasbena komponenta sta v Savinovem ustvarjalnem procesu torej tesno povezani. Vsebinski potek besedilne predloge skladatelj podčrta z vsemi glasbenimi parametri. Soodvisnost kompleksnosti harmonije in spremenljivosti tempa (in dinamike) je izražena na primeru tridelne miniature Luna dremlje, ki je zasnovana tako, da sledi in uresničuje dramatično stopnjevanje besedila. Glasbeni tok prve kitice ${ }^{23}$ je ustrezno "miren« in "piano«, osnovne harmonske funkcije C-dura so, kot posledica samostojnega vodenja glasov, zamegljene z neharmonskimi toni (primer 9).

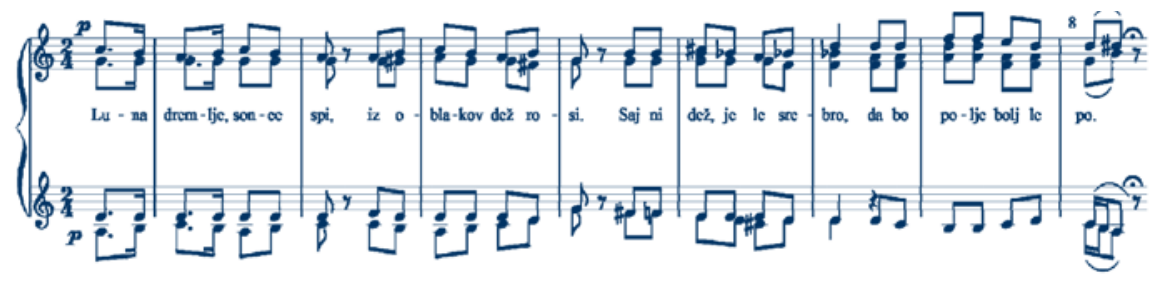

\section{Primer 9: Luna dremlje (takt 1-8)}

Gradivo druge kitice, ki naznani nov dan, ${ }^{24}$ nastopi prvič «veselo« in »mezzoforte», drugič pa, kot sekvenčna ponovitev, "presto« in »forte«. S stopnjevanjem tempa stavek postaja harmonsko enostavnejši, zato je prvi del skladbe najbolj disonančen in 'obložen' s četverozvoki. Presto zaradi učinka in vsebinske dramatizacije ne sme biti preveč zapleten, zato ga skladatelj zreducira na triglasni stavek, višek pa pevci poudarijo z energičnim unisonom (primer 10).

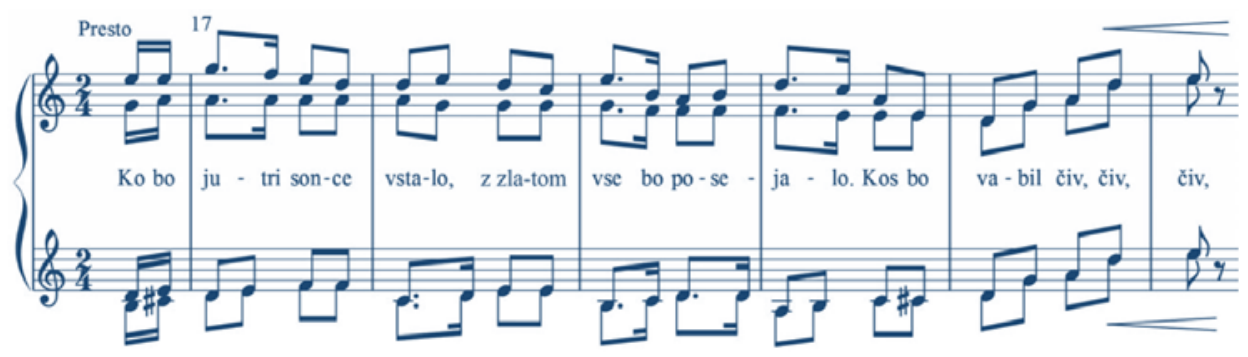

Primer 10: Luna dremlje (takt 17-22)

Četudi je Savin na področje otroškega in mladinskega zborovstva posegel v visoki starosti, njegov prispevek tej zvrsti ni zanemarljiv. Pregled skladateljevega opusa razodeva dva precej kontrastna tipa skladb. Prevladujejo zbori, v katerih je k uglasbitvi besedil pristopil 'resno', v ospredje pa postavil pojmovanje svojega skladanja: harmonijo. Skladbe so diatonične in tonalne. Faktura je gosta, vedno pa vpeta v trden tonalni okvir. Skladatelj ostaja zavezan tonaliteti, ki mu pomeni temelj in ogrodje, tonalni prostor pa ves čas bogati z neharmonskimi, alteriranimi toni. S tem razgiba harmonski stavek, glasbeni tok

23 Uglasbitev verzov Luna dremlje, sonce spi / iz oblakov dež rosi. / Saj ni dež, je le srebro, / da bo polje bolj lepo.

${ }^{24}$ Uglasbitev verzov Ko bo jutri sonce vstalo, / z zlatom vse bo posejalo. / Kos bo vabil čiv, čiv, čiv, / pridi gledat, če si živ. 
pa privede mestoma v precej nasičene zvočne gmote. Dela so zasnovana homofono, čeprav pogosto izstopa latentno linearno vodenje glasov, zaradi česar nastajajo tudi ostra disonančna sozvočja. Melodijo vodi večinoma silabično v sekundah, z mestoma večjimi intervalnimi toni.

Drugi način je v izrazu precej kontrasten: skladatelj skuša značaj besedila prenesti v glasbo tokrat na drugačen, bolj izviren način. Skladbe so harmonsko preprostejše, faktura je bolj prosojna, glasbena govorica pa primerno hudomušna. Besedilo 'obleče' v harmonski stavek, ki je v osnovi precej jasen, a začinjen z občasnimi neharmonskimi toni - tradicionalno postavi v glasbo svojega časa. Tak način je značilen predvsem za uglasbitve preprostih besedilnih predlog pesmi Otona Župančiča (op. 46); nekatere med njimi so se - morda ravno zaradi skladateljevega svežega pristopa - kot redke izmed Savinovih mladinskih del uspele uvrstiti v slovenski zborovski repertoar. Ostali zbori dobijo namreč le malokrat (če sploh) priložnost, da zazvenijo na pevskem odru. ${ }^{25}$ Predvsem prva opusa, 36 in 40, sta za mlade pevce tehnično precej zahtevna; kar niti ni presenetljivo, saj so to skladateljevi prvi poskusi na tovrstnem področju. Ostale skladbe so mladim pevcem vendarle bolj dostopne; ${ }^{26}$ na to je morda vplival skladateljev stalni stik z vodilnimi pevovodji tistega časa, ki bi lahko vplivali na Savina, sicer odprtega za konstruktivno kritiko in dobronamerne nasvete. Svoje zadnje zborovske skladbe je tako prilagodil mladinskim glasovom ter dojemljivosti in sposobnostim pevcev. Prav vse pa bi lahko bile pomembna obogatitev mladinske zborovske literature.

\section{SUMMARY}

Risto Savin's output for children's and youth choirs is one of the least known parts of the composer's oeuvre. The only author who has discussed it in detail is Gorazd Kozmus in his BA dissertation "Risto Savin - analiza zborovskih del" ('Risto Savin - Analysis of Choral Works') and his MPhil dissertation "Problemi poustvarjanja mladinskih in otroških zborovskih del skladatelja Rista Savina" ('Problems in Performance of Youth and Children's Choirs of the Composer Risto Savin') (both at the Academy of Music, University of Ljubljana, 1997 and 2002 respectively). Both of these dissertations remain unpublished and are thus not accessible to a wider audience. This article aims to fill this lacuna and adopts an analytical approach to present the essential compositional characteristics of Savin's pieces for children and youth. Savin wrote his first compositions for youth at the ripe old age of nearly eighty, but managed to contribute some weighty works which became successfully established in the Slovene repertory. The pieces are generally attractive; their musical language is modern and fresh, though still closely attached to traditional functional harmony. Savin does not give up tonality, but blurs it with numerous alterations of non-harmonic notes, and occasionally sharp dissonances. Other musical parameters are quite subordinate to the composer's harmonic thinking.

25 Na podlagi obstoječih virov naj bi bile v preteklosti izvajane naslednje skladbice: Maj; Pomladi; Luna dremlje; Materino srce; Tja v ogrado; Tički po zraku letajo; Kroparji; Zvonovi; Stari medo; Pesem nagajivka. Seznam je le okviren, saj v raziskavi niso bili zajeti vsi minuli lokalni pevski dogodki, kjer bi se pesmi potencialno lahko izvajale. Prim. Kozmus, Problemi poustvarjanja ..., 38-52; Budkovič, Razvoj mladinskega zborovskega petja..., 68.

26 Kozmusov analitični prerez sicer pokaže, da je bila večina Savinovih zborovskih skladbic za mladinski sestav višje zahtevnosti. Prim: Kozmus, Problemi poustvarjanja ..., 91-139. 